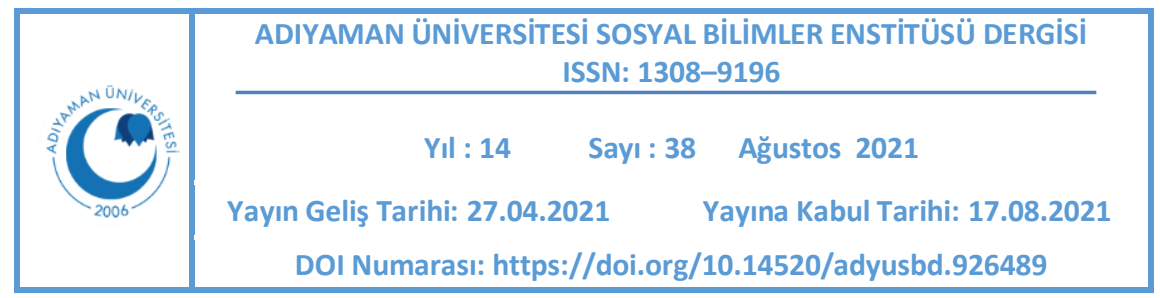

\title{
HANNAH COWLEY'S THE BELLE'S STRATAGEM: THE RELATIONSHIP OF WOMAN TO MAN AND MARRIAGE
}

\section{Zeliha KURUDUCU*}

\begin{abstract}
Hannah Cowley's play The Belle's Stratagem appeared on stage in 1819. The play focuses on the political standpoint of a young attractive English woman, Letitia Hardy. She imagines an arranged marriage with a man from her childhood. The story is structured around the events that happen between Letitia and her future partner, Doricout. Doricourt is a young, handsome, and wealthy man who loves traveling and having much fun. Upon meeting with Letitia, Doricourt is not interested in her even she is a beautiful and rich woman. However, Letitia does not give up and plans to make Doricourt fall in love with her. With her intelligent, courageous, independent nature, Letitia is a very distinctive character when a woman does not discover such virtues. Thus, this study explores Cowley's play as an example of feminist writing in the era. Hannah Cowley is regarded as an early feminist writer who contributes to the rise of women's liberation and right in a male-dominated society. Therefore, this paper analyzes the woman and its early history and their relations to patriarchy, male domain, and marriage institution.
\end{abstract}

Keywords: Feminism, Patriarchy, Identity, Gender, Power

Öğr. Gör., Karabük Üniversitesi, Yabancı Diller Yüksekokulu email: zelihakuruducu@karabuk.edu.tr 


\title{
HANNAH COWLEY'IN THE BELLE'S STRATAGEM OYUNU: KADININ ERKEK VE EVLILIKLE ILIŞKISI
}

\begin{abstract}
$\ddot{O} z$
Hannah Cowley'in The Belle's Stratagem oyunu 1819'da sahnelenmiştir. Oyun genç ve çekici bir İngiliz kadın Letitia Hardy'nin politik duruşuna odaklanır. Letitia çocukluğundan beri bir adamla görücü usulü bir evlilik hayal etmektedir. Hikâye, Letitia ile gelecekteki partneri Doricout arasında gelişen olaylar etrafında şekillenir. Doricourt, seyahat etmeyi ve eğlenmeyi seven genç, yakışıklı ve zengin bir adamdır. Doricourt Letitia ile karşılaştığında, güzel ve zengin bir kadın olmasına rağmen onunla ilgilenmez. Ancak Letitia pes etmez ve Doricourt'u kendisine aşık etmeyi planlar. Zeki, cesur ve bağımsız doğasıyla Letitia, bir kadının bu tür erdemleri çoğunlukla keşfedemediği bir dönemde oldukça farklı bir karakterdir. Bu nedenle, bu çalışma Cowley'in oyununu çağının feminist bir metin örneği olarak incelemeyi amaçlamaktadır. Hannah Cowley, erkek egemen bir toplumda kadın özgürlüğünün ve hakkının yükselişine katkıda bulunan erken dönem feminist bir yazar olarak kabul edilmektedir. Bu yüzden, bu çalışma kadını ve onun erken tarihini ve bunların ataerkillik, erkek alanı ve evlilik kurumu ile ilişkilerini analiz etmektedir.
\end{abstract}

Anahtar Kelimeler: Feminizm, Ataerkillik, Kimlik, Cinsiyet, Güç

\section{INTRODUCTION}

This paper aims to explore Cowley's play The Belle's Stratagem (1819) as an example of feminist writing. The study begins with the historical background and the experiences of women in a male-dominated society. The greatest concern here is the structure of patriarchy and its influence on both men and women economically, politically, and socially. Besides, under the shade of feminist discourse, the woman's condition and its liberation history are briefly discussed. The most well-known feminist critics' perspectives are given by giving some references from their works. Here, Monique Witting, Susan Bordo, 
Mary Wollstonecraft, and Simon de Beauvoir are articulated with some of their specific claims and concerns on gender, woman issue, feminism, and their relation to man, patriarchy, and marriage institution. And finally, Cowley's play The Belle's Stratagem (1819) is analyzed in detail with the application of the feminist discourse and their relation to man, patriarchy, and marriage institution that spearhead the history of man and woman so far.

\section{HISTORICAL BACKGROUND}

The issue of gender discrimination is as old as human history. However, its theorization in the academy is not as old as it is. After some socio-political changes in human history, such as the French and Industrial Revolution, two World Wars, improvements in technology and science, the traditional forms and understandings are started to be questioned. The domain of some institutions such as patriarchy has shattered accordingly. Thus, gender and mainly femininity come into a discussion topic in political, social, and academic arenas, under the umbrella of gender and feminist theories and movements.

Accordingly, some critics started to write and discuss the issue using traditional and new coming discourses to find "a voice for the woman" worldwide, not only in Europe. For example, Monique Witting gives many studies about the issue. She points out that "categories of man and woman are political categories and not natural givens. It puts [women] in a position of fighting" (Witting, 2003, p.7) for the defense of woman and its reinforcement. Likewise, for other feminist critics, Witting focuses on the place of women in society. She (2003) criticizes the fact that women are considered inferior to men because of their so-called insufficient wisdom and thinking ability. She (2003) points out how their sensitive, emotional, and childlike expressions always make them need manpower and ration within times. They are regarded as domestic 'brutes' who are knocked in the kitchen just dealing with domestic works like cooking, 
chopping, cleaning, etc. This construction of femininity requires that women should learn to cook and feed others. They are responsible for household and childcaring even if all these works are regarded as unnecessary or easy to do. Most of the time, they are not given any respect by the opposite sexes who do not have to tackle their world. They are in a world of the kitchen and a bedroom where they are sexual objects suitable for the men's desires and wishes. They are regarded as knowledge of relevant partners of men. Even young women are told that they should respond pleasurably to men's sexual needs. They should blindly obey their masters and learn to live under the protection of their fathers, husbands, etc. They have always been desired by men and much more to be a good wife for them.

Contrary to women's place in a dominant male society, men have been the central figures who have significant powers to domain women and be almost rational in the outside world by using their mind and intellect. It is believed that men are always acting in philosophical manners, unlike behaving in sensitive and emotional ways to know the truth. They are physically and rationally so strong and powerful that they are regarded as much more solid and reliable beings than women. They embody society's masculine values, such as selfcontrolling, ration, determination, authority, power, etc. Both the human body and identity as a man and woman are trained, shaped, and controlled by the male patriarchal community and flawlessly performed in the marriage institution.

Like Witting, Adrienne Rich focuses on the woman issue in her studies, too. In her essay "Compulsory Heterosexuality and Lesbian Existence," Rich (1980) gives Kathleen Gough's list of male dominion society's essential characteristics. She (1980) points out the men's use of women as bride price, arranged marriage, and women as entertainment objects like call girls, geishas, etc. Similarly, she 
(1980) criticizes how they command their labor and control their product. There has been a great inequality between men and women in paid employment in the outside world. Women are constantly being paid less. They are working under demanding working conditions while women are already working inside the unpaid occupation of childcaring and households like cooking, cleaning, etc. Primarily, men do not permit women's creativeness in the male-centered social and cultural arena. For example, women who are regarded as lacking rational minds and far more hysteric natures are rejected from the literary world. They are even deprived of getting an education. There are so many other examples that show how male power has been held since the early ages of history. Women face cultural and economic oppression, which leads to gender inequality and a physical violation that enables manpower and authority. Thus, they are assumed as physically weak and defenseless without male figures. They consider themselves inferior and invisible beings who are forced to be at home before or after getting married. First, they are the properties of their fathers. Then they become their husbands'. From their earlier life, they are taught to be passive, silent, and obedient so that they become lack of coping with the real-life issues and complete their individuality (identity). Therefore, women in history "lived lives in which they were legal without status, politically voiceless and domestically subordinated" (Johns, 2010, p.175).

In this sense, recognizable feminist vision aims to maintain 'consciousness rising' and create social changes in the male-centered community. All feminist scholars are underlining the 'false consciousness created and used by men for their favors without regarding women's rights and desires. 'The myth of woman,' women are inferior, or lack than men are the general assumptions among society. Men have held the violation of power and women's oppression with the help of such an imagined understanding. Simon De Beauvoir asserts this fact as: 
Hannah Cowley's The Belle's Stratagem: The Relationship of Woman to Man and

[the] representation of the world, like the world itself, is the work of men; they describe it from their own point of view, which they confuse with the absolute truth (Beauvoir, 1949, p. 143).

Accordingly, Cowley's comedy The Belle's Stratagem (1819) portrays the world's mythic representation with its men and women many years before her counterparts' writings on the issue. Cowley is brilliant in making fun of this imaginary and fictitious truth, ironically with a fictional text. In the final scene, her characters wear masks. Metaphorically, by doing so, she manages to give her ultimate message:

how the "true" self is nothing more than a provisional category; the mask neither covers an "authentic" identity nor reveals the "opposite" of the truth since the categories of a "true" and "false" identity collapse into one another (Wallace, 2002, p.415).

Cowley's masked and authentic women characters provide a movement or freedom from any identity and any fixed names used to fulfill the patriarchy and its requirements (Wallace, 2002, p.415). However, Cowley celebrates literature's power, enabling her freedom to make another truth opposing the traditional one.

\section{THE BELLE'S STRATAGEM}

The Belle's Stratagem is a five act and sixteen-scene comedy. There are many male and female characters in the play. The main characters are Letitia Hardy, Doricourt, Mrs. Racket, Mr. Hardy, Sir George Touchwood, and Lady Frances Touchwood. The story is structured around the events that happen between Letitia and her future partner, Doricourt. Doricourt is a young, handsome, and wealthy man who loves traveling and having much fun. Upon meeting with 
Letitia, Doricourt is not interested in her even she is a beautiful and rich woman. However, Letitia never gives up and plans to make Doricourt fall in love with her. With her intelligent, courageous, independent nature, Letitia is a very distinctive character when such virtues are not primarily discovered in the woman.

Letitia Hardy Cowley's most authentic character. Differently, she has a personality who is eager to be free and independent. She is someone who looks for passion and desire when she gets married to someone. Even the match was made by the parents, Letitia wants to "make [Doricourt] [her] partner-not for life, but through the foft mazes of a minuet" (Cowley, 1819, 4.1.p.53). However, Mrs. Racket advises her with "the good old maxim - "Marry firft, and love will follow?" (Cowley, 1819,4.1. p.53).

Like Letitia, Doricourt has an independent soul, and he looks for passion, love, and desire from the woman she will his future partner. After their first meeting, Doricourt seems that he is not interested in her much:

Sav. Has the event answered? Did your heart leap, or sink, when you beheld your Mistress?

Doric. Faith, neither one nor t'other; she's a fine girl, as far as mere flesh and blood goes. - - But-

Sav. But what?

Doric. Why she's only a fine girl; complexion, shape, and features; nothing more.

Sav. Is not that enough?

Doric.No! she should have spirit! fire! l'air enjoué! that something, that nothing, which everybody feels, and which nobody can describe, in the resistless charmers of Italy and France. (Cowley, 1819, 1.3.p.9). 
Savilla is so surprised that he feels lucky for not having the same experiences with Doricourt. He "thanks to the parsimony of [his] father, that kept [him] from travel! [he would not have lost [his] relish for true, unaffected English beauty, to have been quarrell'd for by all the Belles of Versailles and Florence" (Cowley, 1819, 1.3.p.9).

On the other side, according to Doricourt, Letitia Hardy is not an ideal "lady" comparing to the one in his image- indeed, the idea is structured around the patriarchal ideology. However, Letitia is so strong and intelligent that she does not act submissively and leave her fate to others' expectations. Yet Letitia uses her intelligence and puts her plan into practice. She hides with a mask and starts behaving like a "lady," which captures Doricourt's taste and interest. Susan Bordo (1993) describes the eighteen-century ideal lady as such:

The nineteenth-century "lady" was idealized in terms of delicacy and dreaminess, sexual passivity, and a charmingly labile and capricious emotionality. Such notions are reformalized in the 1950 s and early 1960s, which was a period of a reassertion of domesticity and dependency as the feminine ideal (Bordo, 1993, p. 2367).

In the masquerade scene, Doricourt is highly influenced by Letitia without having any idea about whether the lady behind the mask is Letitia herself. He starts behaving her as his "Angel" and his "charming Bride":

Dor. I am yet in a state of intoxication-I cannot help an|swer you. - Speak on, sweet Angel! 
Let. You see I can be anything; chuse then my cha|racter-your Taste shall fix it. Shall I be an English Wife? -or, breaking from the bonds of Nature and Education, step forth to the world in all the captivating glare of Foreign Manners?

Dor. You shall be nothing but yourself-nothing can be captivating that you are not. I will not wrong your penetration by pretending that you won my heart at the first interview, but you have now my whole soul-your person, your face, your mind, I would not exchange for those of any other Woman breathing. (Cowley, 1819, 5.5.p.81).

Letitia becomes successful in her plan and makes Doricourt falls in love with her and wishes to get married. Letitia interestingly manages to get married regarding her desires and expectations, not the others.

Juxtaposed against Letitia's and Doricourt's vision on marriage are Sir George Touchwood and Lady Frances Touchwood's marriage. They are newly married couples. Lady Frances is an exquisite, beautiful lady. However, her character is very different from Letitia Hardy. She is not as courageous as her. She is very dependent on her husband. She defines herself with her marriage and her presence with her husband. Sir George Touchwood is a narrow-minded man who is very jealous and conservative. He sticks his wife in his male dominion world. He only enables her an "Angelic liberty" as Wollstonecraft describes it within these lines: "Liberty is the mother virtue, and if women are, by their constitution, slaves, and not allowed to breathe the sharp, invigorating air of freedom, they must ever languish like exotics, and be reckoned beautiful flaws in nature" (Wollstonecraft,2001, p. 415). However, as he is a man, he has always been wandering in his world with having power and possessing all moral 
Hannah Cowley's The Belle's Stratagem: The Relationship of Woman to Man and

virtues, and being there as the master of his woman, Lady Frances Touchwood. In his world:

Women are told from their infancy and taught by the example of their mothers, justly termed cunning, the softness of temper, outward obedience, and scrupulous attention to a puerile kind of property, will obtain for them the protection of man; and should they be beautiful, everything else is needless, for at least, twenty years of their lives (Wollstonecraft,2001, p.416).

Thus, he criticizes the women who do not share the same taste and ideas as him, and he calls them "Fine Ladies." According to him, a" Fine Lady":

is seen everywhere but in her own house. She sleeps at home, but she lives all over the town. In her mind, every sentiment gives place to the Lust of Conquest and the vanity of being particular. The feelings of a Wife, and Mother, are lost in the whirl of dissipation. If she continues virtuous, 'tis by chance-and if she preserves her Husband from ruin; 'tis by her dexterity at the CardTable! (Cowley, 1819, 1.1, p. 25).

For Sir George Touchwood, as a "Fine Lady" is outside the house, -in the men's world, she fails to play her predetermined roles of being a good wife and an ideal mother. For centuries, they have been taught to please men by their beauty, charming, and sexual identity. They were locked in the kitchen and practice the minor virtues so that they blindly admit the cultural, political, and intellectual power of men. Under the roof of such an illusion, women have lived alongside men with a narrow mind, lack education, and inexperienced. In their world, women are only regarded as submissive beings. Sir George Touchwood wants his wife to play the old, traditional roles of her ancestors. He does not let 
her get out of her cage and perform regarding her authentic sense and identity. As being so, Mrs. Racket criticizes him in the conversation below:

Mrs. Rack. Is there not something odd in his cha|racter?

Vill. Nothing, but that he is passionately fond of his wife; -and so petulant is his love, that he open'd the cage of a favorite Bullfinch, and sent it to catch Butterflies because she rewarded its song with her kisses.

Mrs. Rack. Intolerable monster! Such a brute de|serves-. (Cowley, 1819, 1.4.p.12).

Mrs. Racket is a free and independent woman who has her taste, elegance, and identity. Unlike Lady Frances Touchwood, Mrs. Racket is an example of a "Fine Lady." Thus, he disliked her. According to him, Mrs. Racket influences his Angelic wife and makes her misbehaved. He sees Mrs. Racket as a risk for their marriage. As a feminist critic Wollstonecraft's depicts the dynamics behind the marriage of Sir George Touchwood and Lady Frances Touchwood in the play with these lines:

If they are really capable of acting rational creatures, let them not treated like slaves, or, like the brutes who are dependent on the reason of man, when they associate with him; but cultivate their minds, give them the salutary, sublime curb of principle. Teach them, in common with man to submit to necessity instead of giving, to render them more pleasing, a sex to morals (Wollstonecraft, 2001, p.415).

Cowley focuses explicitly on the marriage institution indicating the old dynamics behind it. In many respects, there is a strong influence of patriarchy and its 
predetermined roles and expectations. Indeed, they are always there to be performed with a deep inner acceptance. In specific points, it is seen that the characters behave accordingly. However, especially Cowley's women characters behave and act courageously in mocking traditional formulations. The women characters also employ an unconventional way of thinking on marriage institutions. Cowley thinks of marriage as the standard and desirable goal for women. The characters all have a desire to get married. However, Letitia Hardy does not demand a wedding like the Touchwoods. She wants to get married with love, lust, passion, and trust, not because of the traditional expectations and conventional ways. Letitia and Doricourt both "decide on [they are] actions with freedom of a censor" (Cowley,1819,1.1. p.8). As much as her male character Doricourt, Cowley glorifies [her woman] who [is] independent and resourceful, intelligent, and well educated without becoming pedantic and utterly undeterred by the authority that men attempt to impose on them (Gagen, 1990, p.107).

\section{CONCLUSION}

Cowley, different from other women playwrights in her period, gives her message with a lot of fun and humor rather than using aggressive language, making an argument, harsh criticism, or blaming someone/something. Under the shade of witty language and authentic characters, she gives her standpoint on women much earlier than the evoke of feminism as a social and political movement in history. She is knowledgeable and successful in foreseeing the events that will come forth in the following years. Thus, she is seen as one of the primary women intellectual who is delivering her political message on stage in a humorous way. Indeed, Cowley herself is the one who struggles with the male domain in society and in literary canon as being a woman playwright, too. Creatively, she provides the audience to look at the issue and to think about it 
through the eyes of her fictional women characters, who are highly authentic, intelligent, and courageous. Her play, in her period, gained great success. Besides, she influenced her following counterparts a lot. To sum, the feminist literary canon owes her much.

\section{REFERENCES}

Bordo, S. (1993). "From Unbearable Weight: Feminism, Western Culture, and the Body," New York: New York Times Book Review.

Butler, J. (1999). Gender Trouble. London and New York: Routledge.

Cowley, H. (1819). The belle's stratagem, a comedy; by Mrs. Cowley. With prefatory remarks. the only edition existing is faithfully marked with the stage business and stage directions, as it is performed at the theatres royal. By w. oxberry, comedian. London: W. Simpkin and R. Marshall. Clement Chapple [66 Pall Mall]

De Beauvoir, S. (1949, 1952). The Second Sex. New York, NY: Random House.

Gagen, J. (1990). "The Weaker Sex: Hannah Cowley's Treatment of Men in Her Comedies of Courtship and Marriage," in the University of Mississippi Studies in English, Vol. VIII, pp. 107-16.

Johns, A. (2010). Feminism and Utopianism. London: Cambridge University.

Rich, A. C. (1980). "Compulsory Heterosexuality and Lesbian Existence," Journal of Women's History, Volume 15, Number 3, Autumn 2003, pp. 11-48.

Wallace, E.K. (2002) "Theatricality and Cosmopolitanism in Hannah Cowley's The Belle's Stratagem," in Comparative Drama, Vol. 35, No. 3-4, FallWinter, pp. 415-31. 
Hannah Cowley's The Belle's Stratagem: The Relationship of Woman to Man and

Marriage

Wollstonecraft, M. (2001). "A Vindication of the Rights of Woman." Cain, William, et al. The Northern Anthology of Theory and Criticism, United States of America.

Witting, M. (2003). One is not born a woman. In C. McCann (Ed.), Feminist Theory Reader: Local and Global Perspectives (pp. 249-260). New York: Routledge.

\section{GENiŞLETILMiş ÖZET}

Hannah Cowley 18.yy. Ingiliz kadın yazar ve şairlerinin öncü isimlerinden biridir. Aynı zamanda oyunculuk ve yönetmenlik de yapmıştır.

Kişisel yaşantısı hem kadın hem de kadın yazar olarak başarılar ve güçlüklerle doludur. Hemen her alanda olduğu gibi sanat ve edebiyat alanında da erkek egemenliğinin su götürmez bir gerçek olduğu düşünüldüğünde; bir kadın olarak bilim ve sanat dünyasında kendine yer edinmeye çalışmak Cowley için oldukça zor olmuştur. Toplumsal olanın duvarlarına çarpmadan yol almak bugün olduğu gibi o günlerde de güçlüklerle doluydu, özellikle de kadınlar için.

Kişinin kendini yaşam içinde var etme serüveninde kuşkusuz önkoşul toplum içinde toplum ile var olabilmektir. Zira insan türü ancak toplum olabildiği sürece güvenilir ve sağlıklı sürdürülebilir bir yaşamı inşa edebilir. Buna insan türünün aynı zamanda "politik" bir "özne" olduğu gerçeği de eklemlendiğinde, insanın toplum içinde kendini konumlandırdığı nokta ile toplumun bireyi konumlandırdığı nokta çoğu zaman çatışır ve bu çatışma kaçınılmazdır. Bu insanın en keskin ikileminin çatışmasıdır: kendi başına özgür olma istenci ile toplum içinde "biz" olma arzu ve gerekliliği. Bu noktadan bakıldığında Cowley'in öznel serüvenini toplum içindeki yaşantılardan ayırmak mümkün değildir. Yaşamı resmeden misyonu ile sanat, bu noktada Cowley için bir araç işlevi görür. Cowley'in çalışmalarına yansıyansa tam olarak budur: yaşadığı yüzyıldaki öznel ve toplumsal deneyimlerin bir resmi. Öznel dünyasıyla çatışan toplumsal dünya onun eserlerinde en temel çıkış noktası olarak belirir. Cowley var olmaya çalışmanın ne kadar da güç, keskin sınırlarla belirlenmiş (cinsiyet ve sosyo ekonomik kategoriler gibi), meşakkatli bir yol olduğunu fisıldar karakterlerinin kulağına. Bunu yaparken de kullandığı dil ve üslup çağdaşlarının aksine çok daha ironik, sarkastik ve stratejiktir.

İnsanın bu temel çatışmasının içini dolduran pek çok unsur ve dinamik olsa da genelde Cowley'in eserlerinde dikkat çektiği konular şöyle sıralanabilir: toplumsal kimlik çatışması, kadın ve erkek olarak var olmanın dinamikleri, 
ataerkil yapının yaşantıdaki yeri ve üstlendiği roller, toplum olmanın en önemli bileşeni olarak aile, aile kurma ve aile olmanın kadın ve erkek üzerinde nasıl öznel ve toplumsal pratikler haline geldiği gibi.

Cowley'in bu çalışmada incelenen oyunu, The Belle's Stratagem bu dinamiklerin hemen hepsinden kesitler sunmayı başarır okuruna ve izleyicisine. Oyun 1780 yılında Londra'da sahnelenmiştir. Oyunun ismi konusunda Cowley'in İrlandalı oyun yazarı George Farquhar'ın The Beaux Stratagem (1707) oyunundan esinlendiği görülmektedir.

Cowley'in bu oyunu durum komedisinin en iyi örneklerinden biri olarak kabul edilir. Kalabalık bir oyuncu kadrosu vardır. Cowley oyunda yukarıda bahsedilen temel çatışma ve dinamiklerini merkeze alarak şu konuları işler: cinsiyet, kadınlık ve erkeklik, ataerkil yapı ve bir iktidar pratiği olarak kavramsallaştırılabilen evlilik kurumu ve toplumun bu kurum çatısı altından kadın ve erkekten beklentileri. Oyunda ilk göze çarpan Cowley'in ana karakterinin bir erkek değil aksine bir kadın olmasıdır. Erkeğin ve erkek olmanın hemen her yerde olduğu gibi yazı $(m)$ dünyasında da kendisini merkeze konumlandırdığı düşünüldüğünde - zira eserlerindeki erkek kahramanları da merkeze aldıkları görülür- Cowley'in bu çıkışı oldukça istisna ve fakat dikkate değer bir hamledir. Özellikle de içinde yaşadığı çağ göz önünde bulundurulduğunda (18. yy.). Cowley kalemini bir güç olarak kullanmaktan hiç çekinmez. Fakat çok keskin olmaktan da sakınır.

Eserlerindeki karakterlerinin büyük çoğunluğu kadındır; oldukça güçlü, ne yaptığını bilen ve kendi var oluşlarını otantik bir yaşantı olarak deneyimleyebilen; toplum ve erkek karşısında (ataerkil) nasıl konum almaları gerektiği konusunda da yetkin ve zeki kadınlar.

Bu çalışmada incelenen oyunun ana kadın karakteri Letitia karşımıza tam da bu özellikleri kendi bünyesinde taşıyan bir kadın olarak çıkar. Etrafı ataerkil pratiklerle donatılmış olsa da Letitia kendisini bir birey ve kadın olarak var etme serüveninde sık rastlananın aksine (Lady Frances Touchwood örneğinde olduğu gibi) zor bir savaş verir. Kendisine düzen içinde çizilmiş ve sınırları belirlenmiş bir kader sunulsa da -daha beşikte bebekken gelecekte kiminle evleneceği üzerine verilen karar o bunu kabul etmez ve direnir. Oysa Cowley'in bir diğer kadın karakteri Lady Frances Touchwood ne Letitia kadar güçlüdür ne de onun kadar bilinçlidir. Ataerkil dinamiklerin belirlediği ve kadından beklediği her şeyin içinde sıkışan genç, güzel, evli ama mutsuz bir kadındır Touchwood. Cowley Letitia ve Doricourt'un evlenme serüvenin yanına Touchwood çiftini koyarak başarılı bir çatışma oluşturur. Bu sayede ataerkil düzeni, bu düzen içindeki pratikleri ve bir iktidar pratiği olarak evlilik kurumunu bir dizi olay etrafında tartışır. Kadınlık ve 
erkeklik gibi olguları keskin bir eleştiri dili yerine daha ironik bir üslup ile tartışmayı tercih eder. Kadın olmayı ve kadın olarak var olmayı tamamen erkekler dünyasından ayırıp bir ayrıştırma yoluna gitmenin aksine daha dengeli bir orta yolda onları buluşturur. Oyunun sonunda ataerkil düzenin sacayaklarından biri olarak evliliği ve evlilik kurumunu tamamen dışlamak yerine bu sınırlar içinde kalarak kadına ve kadın olarak var olmaya biraz daha özgür bir alan açma yolunu seçer.

Bu bağlamda, Cowley kendisinden sonra gelecek kadın yazarlara hem öncülük eder hem de onlara kadın hak ve özgürlük yolunda ilham olur. Yaşam şekli ve çalışmalarıyla kadının ve kadınlığın politik bir pratik olarak 19.yy. da başlattığı feminist hareket için ilham kaynağı işlevi görür. Diyebiliriz ki Cowley içinde yaşadığı yüzyılda ataerkil yapının dinamiklerini ve pratik yaşamdaki tezahürlerini deneyimleyen bir kadın yazar olarak bu oyununda kadın karakterleri üzerinden bir temsil oluşturmayı başarır. Genel temsile uyan karakterler yerine- toplumsal normlar arasında sıkışmış, ataerkil düzen içinde kendilerine sunulan yeri kabullenmiş ve yağmalanmış, erkek için bir nesneden öteye geçemeyen silik ve sinik kadınlar kadın olarak özgürleşmeye çabalar Cowley'in kadınları. Ve tüm bunları deneyimlerken büyük söylemlerde, eylemlerde ya da ruhsal yıkımlarda bulunmazlar. Aksine Cowley'in dili ve karakterleri şiddet dilinden bir hayli uzaktır. Zekice ve ustaca. 18.yy. da yaşamış bu kadınlar ve anlatılar ne özneldir ne de zamansal.

Öte yandan, Cowley'de yaşamı ve çalışmalarıyla her ne kadar öznel görünse de bireyselin toplumsalla, yerelin evrenselle buluştuğu bir serüvendir: zaman ve mekanla sınırlı kalmayan, dil, din, ırk, dönem fark etmeksizin. Cowley'in eserlerinin hala ilgi görmesinin temelinde yatan da eserlerinin ve resmettiği karakterlerinin evrensele dokunabilmiş olmasıdır. 